\title{
Can mannose-binding lectin activation help in fighting bacterial pathogen in poultry production systems? - A review
}

\section{Peter Ayodeji Idowu ${ }^{1 *}$, Maliviwe Mpayipheli ${ }^{1}$ and Voster Muchenje ${ }^{1}$}

${ }^{1}$ Department of Livestock and Pasture Science, Faculty of Science and Agriculture, University of Fort Hare, P/Bag X1314, Alice, South Africa.

Simple Summary: In the quest to combat poultry related diseases, poultry farmer adopts different methods of which are not economical and less effective in long term. In recent years, level of production in poultry has been greatly affected by bacterial pathogens which in turn lead to great loss at the end of production cycle. Poultry animals possess an innate immunity called mannose binding lectin which could be activated at exposure to poultry related diseases. Nevertheless, most poultry farmers' fails to take advantage of MBL activation based on some management practices adopted. Study on MBL has gained some consideration in human but less attention in poultry production. This review aims at revealing how mannose binding lectin activation can help in fighting bacterial pathogens across different poultry production systems. This includes different methods of quantifying and detecting MBL levels, management practices adopted as it affects MBL levels across different age. This knowledge will benefit poultry farmers in curtailing production cost and ensuring poultry animals' welfare without incessant use of antibiotics.

Abstract: Bacterial pathogens have been attributed to poultry housing structure, financial strength, and incessant use of antibiotics, variable seasons and management systems practiced. Variant forms of bacterial pathogens can be detected by recognizing the molecular pattern of the pathogens through an innate immune mechanism such as mannose-binding lectin. Mannosebinding lectin (MBL) possesses an innate pattern recognition molecule that easily sequestered to region of infections and inflammations. This works by attaching itself to antigen surface thus hinders proliferation and disease activity in the host organism. Baker's method, nephelometric assays technique, Enzyme-Linked Immunosurbent Assay technique, Polymerase Chain Reaction, Deoxyribonucleic Acid typing and other biotechnology related methods are techniques used in detecting and quantifying MBL. Mannose-binding lectin levels in serum can be influenced by age, management systems, feed formulation strategies and seasons. Therefore, knowledge of MBL should be encouraged in all aspect of poultry production, in order to discourage incessant use of drugs at a slight exposure to prevailing bacterial which can help in maximizing cost.

Keywords: mannose-binding lectin, poultry, production system, pathogens, innate immune response 


\section{Introduction}

Poultry production success recently has been categorized based on nutrition, breeding techniques and management practices adopted [1]. The poultry management systems are based on the poultry production size and can be simplified according to free range or backyard [2], improved backyard [3], semi-intensive or smallholder production and intensive systems or commercial production [4-5]. Out of all the aforementioned management systems, commercial poultry production is known for its role in fulfilling the ever-increasing demand of poultry products. Farmers are confronted with various issues in cultivating operations and management strategies, out of which diseases thrives a lot as a major challenge [6]. Despite the development of commercial poultry production in different countries, smallholder farming system takes a large percentage in meeting the demand of the country at large [7].

Smallholder farming system has a long dated history that makes it prevalent with the rustic and certain urban populaces. Among other poultry production types, smallholder farming system account for about $90 \%$ of the national production [7-8]. Backyard production system (BPS) is the easily adopted type of poultry production methods in most part of rural areas [9]; most farmers embraced this practice as a major source of livelihood and a means to penury reduction [10-11]. Poultry birds are kept in a low put-in yield structure, with little rummaging feed rarely supplemented with edibles leftovers and grains. Poultry and their by-products are normally devoured by their owners, sold locally and utilized as donations [9]. In BPS, chicken becomes more prone to infectious and contagious diseases due to close contact with each other; because such practices expose healthy animals to infected animals [13].

\section{Disease mostly affecting poultry production systems}

The diseases mostly predominant in poultry production are Newcastle diseases, Fowl Pox, Fowl Cholera, Infectious Bursal Disease (IBD), Mycoplasmosis, Salmonellosis, Colibacillosis, Escherichia coli and Campylobacter spp. among others. These diseases are combated with vaccination and for some reasons unknown, vaccination becomes expensive and ineffective in some cases hereby, putting farmers in a state of great loss [14-15]. Bacterial infection in chicken is one of the major threats regarding feed efficiency, animal welfare and food security. They are key vector of food-borne disease mostly prevailing in poultry production systems [16]. Bacterial pathogens prevalence in poultry production is caused by variability in housing structure and inadequate dietary supplementation [16;81]. Diverse forms of bacterial pathogens can be detected by recognizing the molecular pattern of the pathogens through an innate immune mechanism [17], identification of specificities of antigens and nature of response [18]. However, the ideal improvement of poultry bird's immune response is of great concern to poultry farmers [19-20]. When health is affected, assimilation and retention of nutrients is prejudiced which affects animals' health. When poultry health is affected, it could results to complement system activities such as receptor specificities in gut and activation of mannose-binding lectin [21-22]. Poultry has been recorded as one of the major source of human infection due to its availability and cost effectiveness [29]. Bacterial infection among other infection has in long term poised a major threat in chicken production, its prevention and treatment seems expensive. In recent years, several studies have featured the significance of innate immunity. In this review, we will focus on the major role of MBL, its mode of protection, its detection and quantifying mechanism and its impact in fighting bacterial pathogens within poultry production system 


\section{Mannose- binding lectin structure and function}

There is no generalized nomenclature under International Union of Immunological Societies (IUIS) for mannose-binding lectin. [35, 23] which explain the structure of MBL. Mannosebinding lectin has a bunch like structure with different oligomeric structures which has been predicted in different forms such as: dimers, trimers, tetramers, hexamers. Mannose-binding lectin express its orientation mostly in tetramers shape with its readiness to activates complement system thereafter knit itself to the surface of microbes [36, 37]. [Fig1]

Mannose-binding lectin also has four exons with different functions. Three indistinguishable peptide chains of 32 kilo dalton $(\mathrm{kDa})$ made up the subunits, which accumulation of many subunits forms the higher order oligomers of mannose-binding lectin [27,28, 38]. Three of such affixes associate to give a classical collagenous triple helix [39]. Each chain has a lectin domain, wound loop hydrophobic neck region (containing 30 amino acids, collagen-like space and CRD area), a cysteine-rich $\mathrm{N}$-terminal region and a collagenous region(115 amino acids)[40].Cysteine deposits in the cysteine-rich region forms inter-chain disulfide link forming an oligomerization.

The cysteine- rich region has ultimate function to detect carbohydrates on pathogens [41]; with potency to bind to wide range of sugar such as $\mathrm{N}$-acetyl-D-glucosamine, mannose, N-acetylmannosamine, fructose and glucose. Such binding can be expressed as lock (antigen) and key (innate antibody) pattern [42] with great affinity to interact to pathogens such as virus, fungi and bacterial [42]. Mannose-binding lectin is a functioning member of collectin family possessing an antibody affinity with regards to its molecular structure, which helps in attacking antigens with little or no variation at binding region [41]. Binding of mannose-binding lectin can be activated by prompting complement fixation on bacterial surface, obstruction of viral infectivity and opsonizing fungi growth before activation of appropriate $A^{b}$ response [19]. Mannose-binding lectin interfaces with variation of bacterial and viral irresistible pathogens through its Carbohydrate Region Domain (CRD) [19].

\section{Process of binding of MBL to bacterial pathogens in poultry}

Mannose-binding lectin is synthesized by the liver but can be found in nasopharyngeal secretions, inflamed joints, amniotic fluid, and serum. Immune response possesses an innate pattern recognition molecule that easily sequestered to region of infections and inflammations [23-26]. Mannose-binding lectin attaches itself to microbial surfaces by opsonophagocytosis in two different ways. The two ways are: through lectin pathway (bridging gap between innate and adaptive immunity) and through foreign cell lysis $[152,158]$. Mannose-binding lectin serves as first line of protection against foreign invaders, such as bacterial, virus, fungi [158]. Also, it eliminates altered self cells such as necrotic or apoptotic cells, amyloids (protein aggregates) in poultry [158]

The most vital actuation of the supplement activities is by lectin pathway [19]. Lectin pathway is interceded by the mannose-binding lectin associated serine protease (MASP-2) prompting the formation of the $\mathrm{C} 3$ convertase $\mathrm{C} 4 \mathrm{~b} 2 \mathrm{a}$. This then takes charge of the cleavage of $\mathrm{C} 3$ and the age of various $\mathrm{C} 3 \mathrm{~b}$ parts which tie covalently to the surface of the antigens. Such regions are taken by the CR1 (CD35) receptor of the phagocyte. Progressively, some C3b is changed over to iC3b, captured by CR3 receptors. Coordinate action of mannose-binding lectin by phagocytes has been reported in various studies [153, 153, 19, and 41]. But the exact collectin receptor integrated has 
not yet been distinguished [41]. Mannose-binding lectin is equally ready to advance action by a dosage subordinate balance of cytokine discharge from monocytes. The interplay between MBL, MASPs and ficolins are solely dependent on immune status of poultry animal, stage and line of infection or presence of secondary agents of infection [158]

Mannose-binding lectin in apoptosis has been proposed to bind especially to apoptotic $\mathrm{T}$ cells and polymorphonuclear neutrophils through the globular CRD region. [44]. Reproducing ingestion of this ligation on the phagocyte surface of the multi-functional protein, calreticulun has been the mode of action of mannose-binding lectin. Calreticulun (otherwise called the $\mathrm{cC} 1 \mathrm{qR}$ ) bound to the endocytic receptor protein CD91, otherwise called the $\alpha$-2-macroglobulin receptor. Utilization of these proteins gives another case of apoptotic cell autonomy which is catalyzed by mode of activation of the affected and self-cell structure.

Mannose-binding lectin fights bacterial by a mechanism called "Ante-antibody" [158]. Anteantibody is disease modifier molecules which performs a function both at early stage and at later stage before adaptive system develops antibody production mechanism [158-159]. Protein nature of mannose-binding lectin permits provision of a non-specific antigen against bacterial pathogens. After decline of maternal antibodies at stage of exposure, mannose-binding lectin helps in fighting infections before the full active state of antibody repertoire. [44, 152, 153].

Mannose-binding lectin does not only bind bacterial but also binds viral diseases such as avian flu virus (AIV). It straight forwardly represses hemagglutinin action and infectivity of a few strains of AIV. Moreover, MBL goes about as an opsonin; upgrading neutrophil reactivity against AIV [45]. Mannose-binding lectin provides a pre-immune response against AIV [45-46]. Therefore, mannose-binding lectin can bind various strains of bacterial especially in poultry animals by its presence and suitable level of mannose-binding lectin by hindering the growth, development and augmentation of bacterial, viral and fungi pathogens in poultry [47].

The list of some of the bacterial that can mannose-binding lectin can bind are shown on table 1 .

\section{Past and present methods of detecting and quantifying mannose-binding lectin in Poultry}

\section{Bakers Methods}

At early stage, mannose-binding lectin was first detected by its capacity to opsonize heat killed baker's yeast. Its deficiency was generally associated with failure to opsonize yeast bacterial [54]. This was a conventional way of detection known to be economically reasonable. Baker's methods have ability to uncover both quantitative and qualitative data of bacterial present and its nature (pathogenic or non-pathogenic) in sampled organism's analyzed [55-56].Techniques for recognition are as follows: pre enhancement, sample improvement, specific plating, and biochemical screening in relation to serological affirmation. Distinguishing proof of the strains of bacterial consumes time. Hence, demonstrates the requirement for further less time consuming tests [57-58]. Baker's method success relies basically on multiplication ability of organism to reveal visible strains [59-60]. This method is quite labour intensive due to many processes involving expertise to prepare culture medium, inoculating plates and strains counting. It takes time for just identification of viable pathogens [56]. The challenges mentioned leads to reasons to invent such a rapid method. Bakers Methods have this limitation that it can only show the 
quantify activity rather than showing the concentration (gravimetric) of amount of mannosebinding lectin present in the serum [61]. The challenges listed above leads to invention of rapid methods such as nephelometric assay among other rapid assays [62].

\section{Nephelometric Assay Technique}

Nephelometric assay measure permits high-touchy C-reactive protein detection in serum and plasma with specie self-reliability features. It is mostly utilized for pediatric patients, children and can test volume up to 44ul. It has a simple methodology contrasted with Enzyme Linked Immunosurbent Assay (ELISA) and short examining time compared to baker's method yet less dependable than ELISA. It has a short identification scope of $0.09-5.6 \mathrm{ul} / \mathrm{ml}$, because of its short scope of recognition. It can be utilized for some specimen in brief time (Table 2). It gives off an impression of being unsatisfactory after a few years. [61]. It has short range of detection. [62]

\section{Enzyme Linked Immunosurbent Assay Technique}

Enzyme Linked Immunosurbent Assay (ELISA) is a fast, delicate and particular serological test. It is recently known and richly utilized method for measuring MBL protein in serum. Enzyme Linked Immunosurbent Assay reveals the incidence of hormones, peptides, antigens, antibodies, and pathogens utilizing enzyme connected antibodies present in the blood, urine, swab and any other fluids [63-64]. Such strategies include a few brooding strides to paint antibodies, antigens and additionally blocking techniques, track by a progression of washing steps. Protein covering steps may require a brooding period between four hours to twelve hours; consequently, using an ELISA test to identify an analyte may take from a few hours to as long as 24 hours [65]. There are different types of antigens which can be used to coat ELISA plate such as: whole cell antigen, sonicated antigen, potassium thiocyanate extract, glycoprotein antigens, lipoprotein antigens, sodium salicylate extract, and heat extract antigen [66-68]. Antigen to be used can be grouped based on their individual properties such as: specificities, preparation duration, antibodies to be detected, ability to distinguish between infected or immune resistant animals [68].Its target DNA ranges from 0 to 10 um concentration, it shows visible colour from red to blue or grey. The colour changes as the DNA concentration increases [72]. ELISA can be used for detecting other avian species and human.

\section{DNA Typing and Polymerase Chain Reaction (PCR)}

Use of biotechnology techniques such as DNA typing, Genotype typing, PCR techniques: This has really helped in precision and easy detection of bacterial pathogens in liver, blood, swab of chickens [73]. Biotechnology leads to brisk method of an assay, which reveals result within a short time. It helps in early detection and shows variation of microorganism at varying length and numbers [75].Selection of a particular method to be adopted are based on some factors such as choice of testing needed, range of detection, quantity of sample to be analyzed, field of expertise of technologist [75], capital available for purchase of equipment and nature of tools [74]. It is an expensive tool compared to other methods (Table 3). Even though PCR appears to be the latest means of detecting mannose-binding lectin in serum and most powerful, it has the following limitations which are, usage is quite complicating, need a trained personnel. It also require hygienic, high sanitary environment for test procedure. 


\section{Mannose-binding lectin deficiency in poultry}

Poultry wellbeing can be ascertain, provided the immune system produces sufficient amount of mannose-binding lectin (MBL). Mannose-binding lectin produced can then be transfer to the blood hereby, up-regulating the production amid intense phases of infection diseases [86-88]. Mannose-binding lectin deficiency in other word is immunodeficiency, such deficiency results in malfunctioning of innate immunity response. At this point, poultry animal's susceptibility to diseases increases to great number of associated infections [23]. Mannose-binding lectin ties to a scope of clinically significant bacterial pathogens demonstrating a variable example of dependability [43]. It possesses opsonin and lectin pathway activator, which ties across numerous lectin spaces to the rehashing sugar molecules shown on the surface of varied clinically applicable microbial species. [23, 79, 89] reported that liver and serum are the two major areas for isolation of chicken mannose-binding lectin $(\mathrm{cmbl})$ using cmbl-specific monoclonal antibodies. The possibility of comparative absence of mannose-binding lectin may predispose the host to disease [88]. Basically, mannose-binding lectin-subordinate opsonin insufficiency in serum corresponds with a phenotype of intermittent infectivity [89]. Absence of one out of three amino acid single nucleotide polymorphisms (SNPs) in exon 1 of the mannosebinding lectin quality disturbs the collagen helix [90]. Such absence creates the impression that scattered collagen chain acts like a predominant harmful reactions. Scattered collagen chains results in a decline pathway levels of mannose-binding lectin with great likelihood of initiating complement activities, which can lead to its deficiency [21]. Mannose-binding lectin insufficiency and increased bacterial infection in chicken are positively correlated, hereby signifies that mannose-binding lectin sufficiency fights different predisposing infections in poultry animals

\section{Mannose-binding lectin activation: A tool for combating bacterial pathogens in poultry production systems}

Food-borne infections incorporate general classes of ailments with divergent degrees of severity, extending from mild illness to severe ailment caused by either poisons discharged by the vector, or by the organism itself [92, 93]. [94] has a global view of intensifying the aptitude of global and local facilities in the supervision of food borne pathogens such as campylobacter, escherichia, listeria, salmonella among other bacterial pathogens.

Campylobacter spp is known to be pattern less in nature forming wide variation in structure and difficult to trace hereby, forming a store house for diseases [95]. It is one of the main sources of zoonotic enteric diseases in most developing and developed nations [97]. Most of the causes of campylobacter are widely attributed to poultry [98] cattle, pigs, sheep and ostriches, cats and dogs are also carrier of campylobacter [99]. Campylobacter spp is known as the normal human gastroenteritis, which accounts for one of four key worldwide reasons for diarrhea sicknesses [94].Campylobacter affects meat production [95, 101]. On-field inspecting of poultry can be performed by gathering or slaughtering chickens before butcher and taking fecal droppings or swabs from the cloaca $[100,99]$. Study by [101] reveals organically raised flocks of three farms confirmed after strict analysis of seven consecutive crop cycles turnout that colonization of campylobacter in the intestine of chicken is strongly influenced by management practices and not on effect of rearing period duration. In many developing nations like South Africa, the revealed frequency has expanded consistently accounting as the most recent in twenty (20) years, among other enteric infection with constant increase every year [102]. Study by [103] recorded 
geometrical increase of campylobacter in poultry raised under free range management system. Parallel and consistent access to water and soil was linked as a major route for campylobacter infection in poultry [104]. Campylobacter positive flocks were observed to be relatively high among smallholder farming system compared to commercial farming system accounting to about $49 \cdot 2 \%$ and $36.7 \%$ respectively [104]. This could be resulted to incessantly exposure to free grazing, along these lines expanding the quantity of conceivable pathogenic sources $[104,105]$. Chickens should be restricted from roaming around and picking unscreened feed in order to manage bacterial within the chicken house most especially at $4^{\text {th }}$ to $6^{\text {th }}$ week[79], strict hand hygiene practices by consumers, sanitary measures of both animal feed and housing [106], quarantine test before introducing birds from hatchery, children below five years old are mostly prone thus, there is need for conscious cleaning of hands, genetically immune advantageous breed should be considered for production [100]. Mannose-binding lectin appears to be sufficient from day old to beginning of $4^{\text {th }}$ week and from $6^{\text {th }}$ week to adult stage under proper feeding and good management systems [79, 82, and 23].

Escherichia coli (E. coli) are microscopic organisms mostly lives in human and avian digestive organs [107]. [96] reported that E. coli disease results to about 48 million sick patients, 128,000 hospitalized, 3000 death cases from food borne related cases every year in United States, which makes it one of the prevailing bacterial pathogen. E. coli O157:H7, Extra intestinal Pathogenic E.coli (ExPEC) and different strains like E. coli O145 and E. coli O121:H19 deliver a poison called Shiga poison, which causes ailment in people and are in charge of most prevailing related E.coli infections [107, 108]. E. coli microscopic organisms in poultry are not responsible for causing diseases on vector but on any human who consume such infested animals and mostly the digestion tracts serves as shelter for such pathogen [109]. Escherichia coli causes series of illness disorders in poultry, including yolk sac disease, respiratory tract contamination, swollen head disorder, septicemia, airsaculitis and pericarditis [110]. Infections most cases are triggered or activated by predisposing agents, such as bacterial infection, environmentally influenced agents and interaction between bacterial and environment [109].E. coli confines from chicken feacal samples and the poultry house condition attacked the inside organs of tested chickens [111]. Contrary to most findings, destructive related genotypes and phenotypes, incorporating into vivo harmfulness, of fecal exudes from healthy chickens thus, infect both human and poultry by contact with chicken intestine, carcasses, urine and some meat products [112]. E.coli has been a major challenge to poultry production systems, but can be managed under proper management systems, quarantine techniques, avoiding infected animals [113] and crossing of genetically resistant poultry [83].

Salmonella spp has been known to withstand and procreate under low temperature and high thermal condition. In a study reviewed by [114], diverse food-borne related pathogens have been related with the nearness of Salmonella spp. Such items includes meat, chicken, pork and their side-effects, fish, eggs, dairy items, chocolate, breakfast oats, snacks and almonds, shelled nut margarine, newborn child recipe, and pet treats. Salmonella is transmitted by means of the fecaloral course [115], through contact with contaminated poultry birds from various sources, vertical transmission from affected hens and debased feed [116,117].Salmonella infected poultry normally seem healthy, but can shed microscopic organism discontinuously thus, making infected bird (s) which shed microbes hardto be distinguished [117]. Salmonella acknowledges the resistant structure amid attack of intestinal epithelial cells, by distinguishing the pathogenic microorganisms through the enlistment of different phagocytic cell lineages [115]. Range of 
innate immune response is in charge of the early identification, intense control of Salmonella such as neutrophils depletion and mannose-binding lectin [118]. It has been shown that Salmonella attacks the intestinal epithelial layer at the antigen-sampling microfold cells. Subsequently, Salmonella encounter dendrite cells and macrophages, followed by an influx of neutrophils, monocytes and more macrophages [119].Moreover, historically, coccidiosis disease leaves chickens more defenseless to different contaminations, for example, salmonellosis and necrotic enteritis [120,121]. Salmonellosis is affects nourishment and well-being concern of poultry animals, which can cause serious sustenance borne sickness in people, and shows a significant worldwide weight of difficulty in developing and developed countries [122]. Control measures for salmonella in chicken production system are hygienic strategies and proper management practices [123], vaccination using dead animal as inoculums [123], feeding birds with specific antibodies from egg gotten from hyper-immunized hens [124], use of genetically resistant chicken germline [109] and building of innate immune system such as mannose-binding lectin [123].

Listeria spp. is widely seen in temperate region especially in soil, manure/sewage, animal feed, water, poultry feaces or excreta, plant extract and poultry walls [125]. Listeria is generally observed in birds such as poultry, geese, turkey serving as primary host and carrierof listeria, playing a critical function in infecting both the animals and the poultry production system at large [77,127]. Its ability to simulate other bacterial symptoms such as coccidiosis, staphylococcus makes it harder to be detectable [127]. [77] reviewed listeriosis (silage diseases) as to be infrequent but severe food borne disease, of which its causal agent is bacterium listeria monocytogenes. It can also be found in both prepared and processed foods particles and has been greatly linked to high morbidity and mortality most especially in poultry production [129]. Listerioisis symptoms seem not specific with intricate diagnosis. In extreme cases it expresses itself as septicaemia and encephalitis [129]. Age has a great influence in susceptibility to listeriosis. Young birds are susceptible with mortality rate up to $40 \%$ revealing chronic infection and adult seldom has meningo encephalitis and death in some cases. Alteration in immune response, damp/moist conditions, cold and moist litters are factors which lead to easy infection of listeriosis[130-132]. Asian countries recorded 48 cases of listeriosis from 1996 to 2008 in Taiwan [133], In China, 479 isolates were accounted from 1964 to 2010 [128]. Recently, South Africa had 365 cases of listeriosis which were detected in Gauteng, resulting in 28 deaths, which led to closure of an abattoir in Gauteng after some meat samples were tested positive to listeria pathogen [134]. Listeria can be treated by use of systemic antibiotics [135], bacteriophage therapy [136,137], essential oils from plant origin such as thyme, rosemary [138], use of Probiotic [137], use of herbal remedy such as plant extracts [138-140], use of nanotechnology [127], building of innate immune response among which are toll like receptors, cytokines, avian egg antibodies, immunotherapy, mannose-binding lectin [127]. It can be easily prevented and controlled by proper hygiene, proper disposal of rotten food products, water treatment and constant cleaning of water tanks and proper disposal of contaminated silage and not fed to animals [127]

\section{Mannose-binding lectin association with management practices in poultry production systems}

Commercial poultry System: Although, adopting serene environment in commercial production system in combating bacterial pathogens do creates some variability. Such as 
chickens are reared differently from day old to maturity and development of micro flora varies in different poultry animals. Some poultry are hatched under serene environment which inhibit growth of micro flora [142]. At slight exposure to bacterial diseases most of them are affected because their immunity was not developed from hatchery to maturity stage [142]. Commercial system production system mostly put measures against predators by fencing the chicken houses and proper vaccination at different age this act mostly do not allow growth of immune response such as mannose-binding lectin against infection [144]. There is need to formulate feeds that will boost mannose- binding lectin in the production system aiming at sequential increment of productivity level.

Smallholder poultry production systems: plays a major role in socio economic activities [144], gifts and token [145], strengthen in-laws relationship [146], provision of manure [144], with short life cycle and quick turnovers [144] It has low input and output mechanism; it also maximizes low quality available feed for maintenance and high productivity [146].Smallholder farmers have adopted ethno veterinary method with no appropriate measurement techniques [145] due to limited veterinary extension services and this method exposes chicken to bacterial infections among other infections [81]. In smallholder farming systems in their little way, strict consideration are considered in rearing chicken such like consistency in cleaning of chicken house in order to discourage growth of bacterial pathogens [143].Predation and diseases are major factors affecting smallholder farmers in most rural areas because of land topography, establishing healthy management system which build innate immunity such as mannose binding lectin as against incessant use of vaccination and ethno-veterinary practices in cases of low income earner farmers in managing diseases in this region are to be embraced in order to reduce infections.

Age: Mannose-binding lectin level varies at different week in chickens. Indigenous chicken should be discouraged or restricted from grazing at age week 4 to week 7 because the mannosebinding lectin level in chicken at this age reduces and the chicken are prone to be infected with bacterial diseases among other diseases at a slight exposure to unclean food materials $[86,79,23]$.

Season: Study by [143] reveals that season has impact on prevalence of bacterial diseases and summer predisposes chicken to more bacterial diseases, farmers should take some strict management practices at this time of the year in order to discourage bacterial infection within and among the chicken house. Whereas in commercial production system, vaccination and treatment are done at slight exposure to infection, which reduces the immune response to infection at entry hereby discourage the activation of mannose-binding lectin against infections [143]. Quarantine measures, general cleaning and proper management system are still the best ways to hinder proliferation of bacterial in poultry production [145].

Feed Formulation Strategies : Present day dietary and farming procedures have been intended to create range with greater potential for development, yield and bolster effectiveness that have brought about compromising health status [66]. Non starchy polysaccharides are available in plant based feeds which contains organic acids that are easily fermented in the cecum of chickens and such reaction are harmful to growth of pathogens, such fermentation discourages binding of MBL in the serum of chicken hereby predisposing chicken to bacterial infection [148]. Presence of sufficient amount of amino acid in the feed leads to right orientation and binding strength of mannose-binding lectin in the chicken. Amino acids also produce micronutrients such as iron which helps in natural resistance to colonization of pathogens in the 
body system through activation of MBL [92]. Mannose-binding lectin as an associate of $\mathrm{Ca}^{2+}$ dependent animal lectin binds through its CRD and such binding occurs in the presence of calcium; which depicts that feed formulated with calcium supplements deficient inhibits activation of mannose-binding lectin [149]. Immune systems response to pathogenic bacterial diseases was linked to dietary zinc insufficiency [66]. Such as Zinc- Methionine (Zn-Met) as a major component of cellular poultry immunity, Zinc-Sulphur ( $\mathrm{Zn}-\mathrm{Su}$ ) and Zinc-Oxygen ( $\mathrm{Zn}-\mathrm{O})$ in chicks feed in corn- soybean diets [150]. Zn-Met and Zn-O responds to antibody in relation to salmonella pullorum, salmonella eneteritis and Escherichia coli among other bacterial [66]. Invitro macrophage phagocytosis is boosted by Zn-Met supplementations which augment macrophage phagocytosis reaction in young poultry against salmonella and survival of adults against E.coli $[152,153]$.Zinc is a major component of diverse metallo-enzymes such as the one involve in gene replication. DeoxyribonucleicAcid (DNA) and Ribonucleic acid (RNA) polymerase deficient in zinc concentrations reduces the activity of deoxythymidine kinase (zincdependent enzyme). Such effect results in decreasing protein and collagen synthesis $[152,153]$.

Mannose-binding lectin level can be significantly affected by supplementing animal feeds with essential oil such as thymol and carvacrol to poultry diet. As the uses of essential oil gets a rapid attention of poultry farmers, its usage can help in providing an environment for easy binding of lectin to infectious diseases in poultry production [31]. Aromatic compounds separated from plant source are called essential oils. Some studies have been investigated about importance of MBL in channel catfish [31] and rainbow trout Oncorhynchus mykiss [82] and come about show enhancements in weight gain, feed conversion ratio, and insusceptibility to infectious bacterial disease.

According to [79] there is a positive correlation between mice (rat family) and chicken mannosebinding lectin level. Reduction in zinc concentration can affect binding of Mannose-binding lectin in poultry. Broad analysis has been done in observing the connection of nutrition and immunology in human especially in relation to zinc inadequacy [54]. But such impacts in poultry vulnerability and irresistibility to bacterial infections have been vaguely studied [55].

\section{Conclusion and Application}

It is well known that poultry products are generally acceptable due to its availability and cost. Findings from this study elucidates that bacterial is a major threat for poultry production. While the knowledge about mannose-binding lectin can help most poultry farmers to manage bacterial infection throughout divergent rearing season with little or no loss in production. Mannosebinding lectin recognize and bind the surface of bacterial, viruses and fungi by agglutinating microbial surfaces, lysis of Gram-negative bacterial and also opsonize a wide range of potential pathogens for phagocytosis. Mannose-binding lectin also influences phagocytosis in the absence of complement activation through an interaction with one or more collectin receptors. In addition, MBL can alter the function of microbial structures to prevent infection. Mannosebinding lectin levels can be influenced with age, management system, and season and feed formulation strategies. Therefore, it can be said that mannose-binding lectin is a way of maximizing the innate potential of poultry animals against bacterial disease at point of entry before the activation of adaptive immunity. However, Mannose-binding lectin insufficiency has been known to expose chicken to different infections such as virus, fungi and bacterial. Consequently, mannose-binding lectin should be extensively study in poultry production as it is studied in human; such study will help poultry farmers to maximize the immunosuppressant 
428 ability of poultry animals in order to maintain poultry health across different age and season to 429 enhance food security from farm to fork and to improve productivity and profit. Therefore,

430

431

432

433

434

435

436

437

438

439

440

441

442 knowledge of MBL should be encouraged in all aspect of poultry production, which will leads to cost effectiveness in usage of drugs thus, discourage incessant use of drugs, consideration of exposure to prevailing bacterial.

Funding: Most of the research included in this review was funded by Govan Mbeki Research Development Research (GMRDC), University of Fort Hare (Project number C346) "Can mannose binding lectin activation helps in fighting bacterial pathogens in poultry production systems?" (2017-2018)

Acknowledgements: The author gladly appreciates Govan Mbeki Research Development Center (GMRDC), University of Fort Hare South Africa for her financial support.

Conflict of Interest: Authors declare no conflict of interest. 
444

445

446

447

448

449

450

451

452

453

454

455

456

457

458

459

460

461

462

463

464

465

466

467

468

469

470

471

472

1. Khan, M.S.; Pande, T; and van de Ven, T.G. Qualitative and quantitative detection of T7 bacteriophages using paper based sandwich ELISA. Colloids and Surfaces B: Biointerfaces, 2015, 132, pp.264-270

2. Herrero, M.; Thornton, P.K.; Notenbaert, A.M.; Wood, S., Msangi, S.; Freeman, H.A.; Bossio, D.; Dixon, J.; Peters, M.; van de Steeg, J; and Lynam, J. Smart investments in sustainable food production: revisiting mixed crop-livestock systems. Science, 2010, 327(5967), pp.822-825.

3. Akidarju, M.S.; Onyemaechi, E.G.; and Dauda, M.G. An assessment of some poultry management practices and disease recognition by poultry farmers in Maiduguri arid zone, Nigeria. World's Poultry Science Journal, 2010, 66(2), pp.285-296.

4. Branckaert, R.D.S.; Guéye, E.F. 2000. FAO's programme for support to family poultry production'. http://www.husdyr.kkvl.dk.htm/php/tune99/24-Branckaert.htm

5. Aini, I. Indigenous chicken production in South-east Asia. World's Poultry Science Journal, 1990, 46(1), pp.51-57.

6. Hamilton-West, C.; Rojas, H.; Pinto, J., Orozco, J.; Herve-Claude, L.P.; and Urcelay, S. Characterization of backyard poultry production systems and disease risk in the central zone of Chile. Research in veterinary science, 2012, 93(1), pp.121-124

7. Saleque, M.A. Poultry as a tool in poverty alleviation: a special program for the rural poor in Bangladesh. In Proceedings of the 2nd International Poultry Show and Seminar, Dhaka, Bangladesh, The World's Poultry Science Association, Bangladesh Branch 2001 (pp. 66-76).

8. Islam, M.S.; Takashi, S.; Chhabi, K.Q.N. Current scenario of the small-scale broiler farming in Bangladesh: Potentials for the future projection. International Journal of Poultry Science, . 2010, 9(5), pp.440-445. 
473

474

475

476

477

478

479

480

481

482

483

484

485

486

487

488

489

490

491

492

493

494

495

496

497

498

499

500

501

502

503

9. Conan, A.; Goutard, F.L.; Sorn, S.; Vong, S. Biosecurity measures for backyard poultry in developing countries: a systematic review. BMC veterinary research, 2012, 8(1), p.240.

10 Dolberg, F. November. Poultry production for livelihood improvement and poverty alleviation. In Poultry in the 21st Century: Avian influenza and beyond. Proceedings of the International Poultry Conference, held 2007, (pp. 5-7).

11 Sonaiya, E.B. Family poultry, food security and the impact of HPAI. World's Poultry Science Journal, 2007, 63(1), pp.132-138.

12 Conan, A.; Ponsich, A.; Goutard, F.L.; Khiev, R.; Tarantola, A.; Sorn, S.; Vong, S. A community-based education trial to improve backyard poultry biosecurity in rural Cambodia. Acta tropica, 2013, 125(3), pp.294-302.

13. Iqbal, M. 2009. Controlling avian influenza infections: The challenge of the backyard poultry.

14. Kabir, S.M. The role of probiotics in the poultry industry. International Journal of Molecular Sciences. Aug 12; 2009, 10(8):3531-46.

15. Rokonuzzaman, M.; Jahan, S.S.; Ali, M.S.; Islam, M.A.; Islam, M.S. Growth performance of three broiler strains in winter seasons in Bangladesh. International Journal of Agriculture Poland, Research 3, 2015; pp.308-313.

16. Wigley, P. Immunity to bacterial infection in the chicken. Developmental \& Comparative Immunology, 2013, 41(3), pp.413-417.

17. Harun, M.; Massango, F.A. 2000. Village Production in Mozambique: Farming systems and

participatory

research. http://www.aciar.gov.au/web.nsf/doc/JFRN5J479R/\$file/PR103\%20Chapter\%2017.pdf 
18. Pedersen, C.V. 2002. Production of semi-scavenging chickens in Zimbabwe; Ph.D. Thesis, Royal Veterinary and Agricultural University, Copenhagen, Denmark.

19. Takahashi, K.; Chang, W.C.; Takahashi, M.; Pavlov, V.; Ishida, Y.; La Bonte L.; Shi, L.; Fujita, T.; Stahl, G.L.; Van Cott, E.M. Mannose-binding lectin and its associated proteases (MASPs) mediate coagulation and its deficiency is a risk factor in developing complications from infection, including disseminated intravascular coagulation. Immunobiology, 2011, 216 (1), pp.96-102.

20. O'Garra, A. Cytokines induce the development of functionally heterogeneous $\mathrm{T}$ helper cell subsets. Immunity, 1998, 8(3), pp.275-283.

21. Zhao, L.; Wang, G.; Siegel, P.; He, C.; Wang, H.; Zhao, W.; Zhai, Z.; Tian, F.; Zhao, J.; Zhang, H.; Sun, Z. Quantitative genetic background of the host influences gut microbiomes in chickens. 2013, Scientific reports, 3.

22. Pourhossein, Z.; Qotbi, A.A.A.; Seidavi, A.; Laudadio, V.; Centoducati, G.; Tufarelli, V. Effect of different levels of dietary sweet orange (Citrus sinensis) peel extract on humoral immune system responses in broiler chickens. Animal Science Journal, 2015, 86(1), pp.105-110.

23. Turner, M.W. Mannose-binding lectin: the pluripotent molecule of the innate immune system. Immunology today, 1996, 17(11), pp.532-540.

24. Da Silva, C. T.; de Lima, E.L.S.; de Brito, L.R.P.B.; Silva, J.L.; Coêlho, M.R.C.D.; Muniz, M.T.C.; Silva, P.C.V.; Domingues, A.L.C. Association between polymorphisms of the Mannose-Binding Lectin and Severity of Periportal Fibrosis in Schistosomiasis, in the Northeast of Brazil. Genetic Testing and Molecular Biomarkers, 2017, 21(9), pp.571-576.

25. Kawai, T.; and Akira, S. Toll-like receptors and their crosstalk with other innate receptors in infection and immunity. Immunity, 2011, 34(5), pp.637-650. 
26. Mahler, D.A.; D'urzo, A.; Bateman, E.D.; Özkan, S.A., White, T., Peckitt, C., Lassen, C. and Kramer, B. Concurrent use of indacaterol plus tiotropium in patients with COPD provides superior bronchodilation compared with tiotropium alone: a randomised, double-blind comparison. Thorax, 2012, 67(9), pp.781-788.

27. Ali, Y.M.; Lynch, N.J.; Haleem, K.S.; Fujita, T.; Endo, Y.; Hansen, S.; Holmskov, U.; Takahashi, K.; Stahl, G.L.; Dudler, T.; Girija, U.V. The lectin pathway of complement activation is a critical component of the innate immune response to pneumococcal infection. PLoS pathogens, 2012, 8(7), p.e1002793.

28. Kikushige, Y.; Ishikawa, F.; Miyamoto, T.; Shima, T.; Urata, S.; Yoshimoto, G.; Mori, Y.; Iino, T.; Yamauchi, T.; Eto, T.; Niiro, H. Self-renewing hematopoietic stem cell is the primary target in pathogenesis of human chronic lymphocytic leukemia. Cancer cell, 2011, 20(2), pp.246-259.

29. Cervera, A.; Planas, A.M.; Justicia, C.; Urra, X.; Jensenius, J.C.; Torres, F.; Lozano, F.; Chamorro, A. Genetically-defined deficiency of mannose-binding lectin is associated with protection after experimental stroke in mice and outcome in human stroke. PloS one, 2010, 5(2), p.e8433.

30. Madsen, H.O.; Satz, M.L.; Hogh, B.; Svejgaard, A; Garred, P. Different molecular events result in low protein levels of mannan-binding lectin in populations from southeast Africa and South America. Journal of Immunology, 1998, 161(6), pp.3169-3175.

31 Peterson, B.C.; Peatman, E.; Ourth, D.D. and Waldbieser, G.C. Effects of a phytogenic feed additive on growth performance, susceptibility of channel catfish to Edwardsiella ictaluri and levels of mannose binding lectin. Fish \& shellfish immunology, 2015, 44(1), pp.21-25.

32. Shi, L.; Takahashi, K.; Dundee, J.; Shahroor-Karni, S.; Thiel, S.; Jensenius, J.C.; Gad, F.; Hain, M.R.; Sastry, K.N.; Ezekowitz, R.A.B. Mannose-binding lectin-deficient mice are susceptible to infection with Staphylococcus aureus. Journal of Experimental Medicine, 2004, 199(10), pp.1379-1390. 
33. Møller-Kristensen, M.; Ip, W.E.; Shi, L.; Gowda, L.D.; Hin, M.R.; Thiel, S.; Jensenius,

J.C.; Ezekowitz, R.A.B.; Takahashi, K. Deficiency of mannose-binding lectin greatly increases susceptibility to postburn infection with Pseudomonas aeruginosa. The Journal of Immunology, 2006, 176(3), pp.1769-1775.

572

34. Gomis, S.; Babiuk, L.; Godson, D.L.; Allan, B.; Thrush, T.; Townsend, H.; Willson, P.;

Waters, E. Hecker, R.; Potter, A. Protection of chickens against Escherichia coli infections by DNA containing CpG motifs. Infection and immunity, 2003, 71(2), pp.857-863.

35. Shakib, F.; Schulz, O.; and Sewell, H. A mite subversive: cleavage of CD23 and CD25 by Der p 1 enhances allergenicity. Immunology today, 1998, 19(7), pp.313-316.

36. Yokota, Y.; Arai, T.; Kawasaki, T. Oligomeric structures required for complement activation of serum mannan-binding proteins. Journal Biochemistry (Toyko); 1995, 117:414-9.

37. Nielsen, O.L.; Jensenius, J.C.; Jørgensen, P.H.; Laursen, S.B. Serum levels of chicken mannan-binding lectin (mannose-binding lectin) during virus infections; indication that chicken mannose-binding lectin is an acute phase reactant. Veterinary immunology and immunopathology, 1999, 70(3), pp.309-316.

587

38 Sastry, K.; Herman, G.A.; Day, L. The human mannose-binding protein gene. Exon structure reveals its evolutionary relationship to a human pulmonary surfactant gene and localization to chromosome 10. Journal of Experimental Medicine; 1989, 170:1175-89.

39. Weis, W.I.; Drickamer, K. Trimeric structure of a C-type mannose-binding protein. Structure; 1994, 2:1227-40 origin of the gene encoding a human serum mannose-binding protein. Biochemistry Journal; 
599

600

601

602

603

604

605

606

607

608

609

610

611

612

613

614

615

616

617

618

619

620

621

622

623

624

625

626

627

628

629

630

631

632

633

634

635

636

637

638

639

640

641

41 Turner, M.W. The role of mannose-binding lectin in health and disease. Molecular immunology, 2003, 40(7), pp.423-429.

42. Kishore, U.; Eggleton, P.; Reid, K.B. Modular organization of carbohydrate recognition domains in animal lectins. Matrix Biology 1997, 15:583 \pm 92 .

43.Zhao, F.; Zhao, Z.; Yan, G.; Wang, D.; Ban, Q.; Yu, P.; Zhang, W.; Luo, Y. Polymorphisms in mannose-binding lectin (mannose-binding lectin) gene and their association with mannose-binding lectin protein levels in serum in the Hu sheep. Veterinary immunology and immunopathology, 2011, 140(3), pp.297-302.

44. Ogden, C.A.; Hoffmann, P.R.; Bratton, D.; Ghebrehiwet, B.; Fadok, V.A.; Henson, P.M. C1q and mannose-binding lectin engagement of cell surface calreticulin and CD91 initiates macropinocytosis and uptake of apoptotic cells. Journal of Experimental Medicine, . 2001, 194(6), pp.781-796.

45. Hartshorn, K.L.; Sastry, K.; White, M.R.; Anders, E.M.; Super, M.; Ezekowitz, R.A.; Tauber, A.I. Human mannose-binding protein functions as an opsonin for influenza A viruses. Journal of Clinical Investigation, 1993, 91(4), p.1414.

46. Couzens, L.; Gao, J.; Westgeest, K.; Sandbulte, M.; Lugovtsev, V.; Fouchier, R.; Eichelberger, M. An optimized enzyme-linked lectin assay to measure influenza A virus neuraminidase inhibition antibody titers in human sera. Journal of virological methods, 2014, 210, pp.7-14.

47. Skjoedt, M.O.; Palarasah, Y.; Rasmussen, K.; Vitved, L.; Salomonsen, J.; Kliem, A.; Hansen, S.; Koch, C.; Skjodt, K. Two mannose-binding lectin homologues and an MBLassociated serine protease are expressed in the gut epithelia of the urochordate species Ciona intestinalis. Developmental and Comparative Immunology, 2010, 34(1), pp.59-68.

48. Townsend, R.; Read, R.C.; Turner, M.W.; Klein, N.J.; Jack, D.L. Differential recognition of obligate anaerobic bacterial by human mannose-binding lectin. Clinical and Experimental Immunology, 2001 124(2), pp.223-228.

49. Davidson, P.M.; Doyle, M.; Beuchat, L.; Montville, T. Food microbiology-fundamentals and frontiers. Chemical preservatives and natural antimicrobial compounds, 2001; pp.593-627

50. Super, M.; Levinsky, R. J.; Turner, M.W. The level of mannan-binding protein regulates the binding of complement-derived opsonins to mannan and zymosan at low serum concentrations. Clinical and Experimental Immunology, 1990, 79: 144-150. Doi: 10.1111 j.1365-2249.1990.tb05170.x 
51. Förster-Waldl, E.; Cokoja, L.; Förster, O.; Maurer, W. Mannose-binding lectin: comparison of two assays for the quantification of mannose-binding lectin in the serum of pediatric patients. Journal of immunological methods, 2003, 276(1), pp.143-146.

52. Nonaka, M.; Ma, B.Y.; Ohtani, M.; Yamamoto, A.; Murata, M.; Totani, K.; Ito, Y.; Miwa, K.; Nogami, W.; Kawasaki, N.; Kawasaki, T. Subcellular localization and physiological significance of intracellular mannan-binding protein. Journal of Biological Chemistry, 2007; 282(24), pp.17908-17920

\section{Ulrich-Lynge, S.L.; Dalgaard, T.S.; Norup, L.R.; Song, X.; Sørensen, P; Juul-Madsen,} H.R. Chicken mannose-binding lectin function in relation to antibacteriall activity towards Salmonella enterica. Immunobiology, 2015, 220(5), pp.555-563.

54. Park, S.Y.; Birkhold, S.G.; Kubena, L.F.; Nisbet, D.J; Ricke, S.C. Review on the role of dietary zinc in poultry nutrition, immunity, and reproduction. Biological trace element research, 2004, 101(2), p.147.

55. Gruber, K.; Rink, L. Diet, immunity and inflammation: 5. The role of zinc in immunity and inflammation. 2013. Elsevier Inc. Chapters.

56. Dallal, M.M.S.; Doyle, M.P.; Rezadehbashi, M.; Dabiri, H.; Sanaei, M.; Modarresi, S.; Bakhtiari, R.; Sharifiy, K.; Taremi, M.; Zali, M.R.; Sharifi-Yazdi, M.K. Prevalence and antimicrobial resistance profiles of Salmonella serotypes, Campylobacter and Yersinia spp. isolated from retail chicken and beef, Tehran, Iran. Food Control, 2010, 21(4), pp.388-392.

57.Invitski. D.; Harnid. L.A.; Atanasov. P.; Wilkins. E. Biosensors for detection of pathogenic bacterial Biosensors bioelectronics 1999, 14: 599-624

58. Lu, L.; Chee, G.; Yamada, K.; Jun, S.. Electrochemical impedance spectroscopic technique with a functionalized microwire sensor for rapid detection of foodbornepathogens. Biosensors and Bioelectronics, 2013, 42, pp.492-495.

59. Biswas, A.K., Kondaiah, N., Bheilegaonkar, K.N., Anjaneyulu, A.S.R., Mendiratta, S.K., Jana, C., Singh, H. and Kumar, R.R.. Microbial profiles of frozen trimmings and silver sides prepared at Indian buffalo meat packing plants. Meat science, 2008, 80(2), pp.418-422.

60. Miller, N.D.; Draughon, F.A.; D'Souza, D.H. Real-time reverse-transcriptase-polymerase chain reaction for Salmonella enterica detection from jalapeno and serrano peppers. Foodborne pathogens and disease, 2010, 7(4), pp.367-373.

61. Wang, M.; Chen, Y.; Zhang, Y.; Zhang, L.; Lu, X.; Chen, Z. Mannan-binding lectin directly interacts with Toll-like receptor 4 and suppresses lipopolysaccharide-induced inflammatory cytokine secretion from THP-1 cells. Cellular and molecular immunology, 2011, $8(3)$, p. 265 . 
62 Mandal, P.K.; Biswas, A.K.; Choi, K.; Pal, U.K. Methods for rapid detection of foodborne pathogens: an overview. American Journal of Food Technology, 2011, 6(2), pp.87-102.

63 Cheng, C.M.; Martinez, A.W.; Gong, J.; Mace, C.R.; Phillips, S.T.; Carrilho, E.; Mirica, K.A.; Whitesides, G.M. Paper-based ELISA. Angewandte Chemie International Edition, 2010, 49(28), pp.4771-4774.

64. Henn, A.D.; Wu, S.; Qiu, X.; Ruda, M.; Stover, M.; Yang, H.; Liu, Z.; Welle, S.L.; Holden-Wiltse, J.; Wu, H.; Zand, M.S. High-resolution temporal response patterns to influenza vaccine reveal a distinct human plasma cell gene signature. Scientific reports, 2013, 3, p.2327.

65. Kaiser, P.; Hardt, W.D. Salmonella typhimurium diarrhea: switching the mucosal epithelium from homeostasis to defense. Current opinion in immunology, 2011, 23(4), pp.456463.

66. Amen, M.H.; Al-Daraji, H.J. Effect of dietary Zinc supplementation on some seminal plasma characteristics of broiler breeders' males. International Journal of Poultry Science, 2011, 10(10), pp.814-818.

67. Manfredi, L.; Hill, R.J.; Van de Ven, T.G. Bridging flocculation of PEI-functionalized latex particles using nanocrystalline cellulose. Journal of colloid and interface science, 2011, $360(1)$, pp.117-123.

68. Poolperm, P.; Varinrak, T.; Kataoka, Y.; Tragoolpua, K.; Sawada, T.; Sthitmatee, N. Development and standardization of an in-house indirect Enzyme Immunosurbents Assay (ELISA) for detection of duck antibody to fowl cholera. Journal of Microbiological Methods, 2017, 142, pp.10-14.

69. Lipscombe, R.J.; Lau, Y.L.; Levinsky, R.J.; Sumiya, M.; Summerfield, J.A.; Turner, M.W. Identical point mutation leading to low levels of mannose binding protein and poor $\mathrm{C} 3 \mathrm{~b}$ mediated opsonisation in Chinese and Caucasian populations Immunology Letter. 1992, (32), pp. 253-257

70. Gordon, A.C.; Waheed, U.; Hansen, T.K.; Hitman, G.A.; Garrard, C.S.; Turner, M.W.; Klein, N.J.; Brett, S.J.; Hinds, C.J. Mannose-binding lectin polymorphisms in severe sepsis: relationship to levels, incidence, and outcome. Shock, 2006, 25(1), pp.88-93.

71. Ray, B.; Gaskins, D.L.; Sajdyk, T.J.; Spence, J.P.; Fitz, S.D.; Shekhar, A.; Lahiri, D.K. Restraint stress and repeated corticotrophin-releasing factor receptor activation in the amygdala both increase amyloid- $\beta$ precursor protein and amyloid- $\beta$ peptide but have divergent effects on brain-derived neurotrophic factor and pre-synaptic proteins in the prefrontal cortex of rats. Neuroscience, 2011, 184, pp.139-150.

72. McVey, C.; Huang, F.; Elliott, C.; Cao, C. Endonuclease controlled aggregation of gold nanoparticles for the ultrasensitive detection of pathogenic bacterial DNA. Biosensors and Bioelectronics, 2017, 92, pp.502-508 
733

734

735

736

737

738

739

740

741

742

743

744

745

746

747

748

749

750

751

752

753

754

755

756

757

758

759

760

761

762

763

764

765

766

767

768

769

770

771

772

773

774

775

776

777
73. Conlan, J.W. Neutrophils prevent extracellular colonization of the liver microvasculature by Salmonella typhimurium. Infection and immunity, 1996, 64(3), pp.1043-1047.

74. Vasavada, R.C.; Wysolmerski, J.J.; Broadus, A.E.; Philbrick, W.M. Identification and characterization of a GC-rich promoter of the human parathyroid hormone-related peptide gene. Molecular Endocrinology, 1993, 7(2), pp.273-282.

75. Biswas, S.K.; Sica, A.; Lewis, C.E. Plasticity of macrophage function during tumor progression: regulation by distinct molecular mechanisms. The Journal of Immunology, 2008, 180(4), pp.2011-2017.

76. Skyberg, J.A.; Siek, K.E.; Doetkott, C.; Nolan, L.K.. Biofilm formation by avian Escherichia coli in relation to media, source and phylogeny. Journal of applied microbiology, 2007, 102(2), pp.548-554.

77 Ivanovic, S.; Zutic, M.; Pavlovic, I. Presence of Listeria monocytogenes at goats. Biotechnology Animal Husbandry 2010, 26:193202.

78. Thiel, S.; Møller-Kristensen, M.; Jensen, L.; Jensenius, J.C. Assays for the functional activity of the mannan-binding lectin pathway of complement activation. Immunobiology, 2002., 205(4-5), pp.446-454.

79. Schou, T.W.; Permin, A.; Christensen, J.P.; Cu, H.P.; Juul-Madsen, H.R. Mannanbinding lectin (Mannose-binding lectin) in two chicken breeds and the correlation with experimental Pasteurella multocida infection. Comparative immunology, microbiology and infectious diseases, 2010, 33(3), pp.183-195.

80. Amagliani, G.; Giammarini, C.; Omiccioli, E.; Merati, EG.; Pezzotti, G.; Filippini, G.; Brandi, G.; Magnani M. A combination of diagnostic tools for rapid screening of ovine listeriosis. Res Veterinary Science 2006, 81:185189

81. Idowu, P.A.; Mpayipheli, M.; Muchenje V.. Practices, housing and diseases within indigenous poultry production in Eastern Cape, South Africa, Journal of Agricultural Science, 2018, 10: 111-121. doi: 10.5539/ jas.v10n11p111

82. Filho, R.M.; Carmo, R.F.; Catsman, C.; Souza, C.; Silva, A.; Moura, P.; Tenorio, A.L.; Vasconcelos, L.R.; Cavalcanti, M.D.S.M.; Pereira, L.M. High frequency of variant alleles of the mannose-binding lectin 2 (mannose-binding lectin2) genes are associated with patients infected by hepatitis B virus. Viral immunology, 2010, 23(4), pp.449-453.

83. Stromberg, Z.R.; Johnson, J.R.; Fairbrother, J.M.; Kilbourne, J.; Van Goor, A.; Curtiss 3rd, R.; Mellata, M. Evaluation of Escherichia coli isolates from healthy chickens to determine their potential risk to poultry and human health. PLoS One, 2017, 12(7), p.e0180599. 
84. Lee K.A.; Kim W.J.; Kim H.J.; Kim K.T.; Paik H.D. Antibacteriall activity of Ginseng (Panax ginseng C. A. Meyer) stemsleaves extract produced by subcritical water extraction. International Journal Food Science and Technology2013, 48:947953

85. Crim, S.M.; Iwamoto, M.; Huang, J.Y.; Griffin, P.M.; Gilliss, D.; Cronquist, A.B.; Cartter, M.; Tobin-D'Angelo, M.; Blythe, D.; Smith, K.; Lathrop, S. Incidence and trends of infection with pathogens transmitted commonly through food-Foodborne Diseases Active Surveillance Network, 10 US sites, 2006-2013. MMWR Morbidity Mortality Weekly Report 2014, 63(15), pp.328-32.

86. Laursen, S.B.; Hedemand, J.E.; Thiel, S.; Willis, A.C.; Skriver, E.; Madsen, P.S.; Jensenius, J.C. Collectin in a non-mammalian species. Isolation and characterization of mannan-binding protein (MBP) from chicken serum. Glycobiology 1995, ;5:553 \pm 61

87. Juul-Madsen, H.R.; Norup, L.R.; Jørgensen, P.H.; Handberg, K.J.; Wattrang, E.; Dalgaard, T.S. Crosstalk between innate and adaptive immune responses to infectious bronchitis virus after vaccination and challenge of chickens varying in serum mannose-binding lectin concentrations. Vaccine, 2011, 29(51), pp.9499-9507.

88. Norup, L.R.; Dalgaard, T.S.; Friggens, N.C.; Sørensen, P.; Juul-Madsen, H.R. Influence of chicken serum mannose-binding lectin levels on the immune response towards Escherichia coli. Poultry science, 2009, 88(3), pp.543-553.

89. Farzan, A.; Parrington, L.; Coklin, T.; Cook, A.; Pintar, K.; Pollari, F.; Friendship, R.; Farber, J.; Dixon, B. Detection and characterization of Giardia duodenalis and Cryptosporidium spp. on swine farms in Ontario, Canada. Foodborne Pathogens and Disease, 2011, 8: 1207-1213

90. Muchadeyi, F.C.; Eding, H.; Simianer, H.; Wollny, C.B.A.; Groeneveld, E.; Weigend, S. Mitochondrial DNA D-loop sequences suggest a Southeast Asian and Indian origin of Zimbabwean village chickens. Animal genetics, 2008, 39(6), pp.615-622.

91.Kjærup, R.M.; Norup, L.R.; Skjødt, K.; Dalgaard, T.S.; Juul-Madsen, H.R. Chicken mannose-binding lectin (mannose-binding lectin) gene variants with influence on mannosebinding lectin serum concentrations. Immunogenetics, 2013, 65(6), pp.461-471.

92. Tauxe, R. V.; Doyle, M. P.; Kuchenmüller, T.; Schlundt, J.; Stein, C. E. Evolving public health approaches to the global challenge of foodborne infections. International Journal of Food Microbiology, 2010, 139: S16 - S28.

93. Bar-Shira, E.; Friedman, A. Development and adaptations of innate immunity in the gastrointestinal tract of the newly hatched chick. Developmental \& Comparative Immunology, 2006, 30(10), pp.930-941.

94. World Health Organization, 2016 Campylobacter Fact Sheet December, http://www.who.int/mediacentre/factsheets/fs255/en/ last assessed on 31-08-2018 
95. Kaakoush, N.O.; Castaño-Rodríguez, N.; Mitchell, H.M.; Man, S.M. Global epidemiology of Campylobacter infection. Clinical microbiology reviews, 2015, 28(3), pp.687720.

96. World Health Organization, (WHO) 2013. The global view of campylobacteriosis: report of an expert consultation, Utrecht, Netherlands, 9-11 July 2012.

97. Skarp, C.P.A.; Hänninen, M.L.; Rautelin, H.I.K. Campylobacteriosis: the role of poultry meat. Clinical Microbiology and Infection, 2016, 22(2), pp.103-109.

98. Gölz, G.; Rosner, B.; Hofreuter, D.; Josenhans, C.; Kreienbrock, L.; Löwenstein, A.; Schielke, A.; Stark, K.; Suerbaum, S.; Wieler, L.H.; Alter, T. Relevance of Campylobacter to public health - the need for a One Health approach. International Journal of Medical Microbiology, 2014, 304(7), pp.817-823.

99. Josefsen, M.H.; Bhunia, A.K.; Engvall, E.O.; Fachmann, M.S.; Hoorfar, J.. Monitoring Campylobacter in the poultry production chain-From culture to genes and beyond. Journal of microbiological methods, 2015, 112, pp.118-125.

100. Allen, V.M.; Ridley, A.M.; Harris, J.A.; Newell, D.G.; Powell, L. Influence of production system on the rate of onset of Campylobacter colonization in chicken flocks reared extensively in the United Kingdom. British poultry science, 2011, 52(1), pp.30-39.

101. Newell, D.G.; Koopmans, M.; Verhoef, L.; Duizer, E.; Aidara-Kane, A.; Sprong, H.; Opsteegh, M.; Langelaar, M.; Threfall, J.; Scheutz, F.;van der Giessen, J. Food-borne diseases - the challenges of 20 years ago still persist while new ones continue to emerge. International journal of food microbiology, 2010, 139, pp.S3-S15.

102. Rivoal, K.; Denis, M.; Salvat, G.; Colin, P.; Ermel, G. Molecular characterization of the diversity of Campylobacter spp. isolates collected from a poultry slaughterhouse: analysis of cross-contamination. Letters in Applied Microbiology, 1999, 29(6), pp.370-374.

103. Heuer, O.E.; Pedersen, K.; Andersen, J.S.; Madsen, M. Prevalence and antimicrobial susceptibility of thermophilic Campylobacter in organic and conventional broiler flocks. Letters in Applied Microbiology, 2001, 33: 269-274. doi:10.1046/j.1472-765X.2001.00994.x

104.Garin, B.; Gouali, M.; Wouafo, M.; Perchec, A.M.; Thu, P.M.; Ravaonindrina, N.; Urbès, F.; Gay, M.; Diawara, A.; Leclercq, A.; Rocourt, J. Prevalence, quantification and antimicrobial resistance of Campylobacter spp. on chicken neck-skins at points of slaughter in 5 major cities located on 4 continents. International journal of food microbiology, 2012, 157(1), pp.102-107.

105. Colles, F.M.; McCarthy, N.D.; Sheppard, S.K.; Layton, R.; Maiden, M.C. Comparison of Campylobacter populations isolated from a free-range broiler flock before and after slaughter. International journal of food microbiology, 2010, 137(2), pp.259-264.

106. Gaffga, N.H.; Behravesh, C.B.; Ettestad, P.J.; Smelser, C.B.; Rhorer, A.R.; Cronquist, A.B.; Comstock, N.A.; Bidol, S.A.; Patel, N.J.; Gerner-Smidt, P.; Keene, W.E. Outbreak of 
salmonellosis linked to live poultry from a mail-order hatchery. New England Journal of Medicine, 2012, 366(22), pp.2065-2073.

107. Lim, W.; Song, G. Pivotal roles for hormonally regulated expression of the HEP21 gene in the reproductive tract of chickens for oviduct development and in ovarian carcinogenesis. Domestic animal endocrinology, 2014, 48, pp.136-144.

108. Mead, G. Campylobacter update-the challenge. International Poultry Production, 2004, 12(4), pp.26-29.

109. Magdalena C.; Helena H.; Marcela F.; Marta M.; Hana H.; Frantisek S.; Ivan R. "Immune Response of Chicken Gut to Natural Colonization by Gut Microflora and to Salmonella enterica Serovar Enteritidis Infection" infection and immunity, 2011; p. 2755-2763

110. Skyberg, J.A.; Logue, C.M.; Nolan, L.K. Virulence genotyping of Salmonella spp. with multiplex PCR. Avian diseases, 2006, 50(1), pp.77-81.

111. Ewers, C.; Antão, E.M.; Diehl, I.; Philipp, H.C.; Wieler, L.H. Intestine and environment of the chicken as reservoirs for extraintestinal pathogenic Escherichia coli strains with zoonotic potential. Applied and Environmental Microbiology, 2009, 75(1), pp.184-192.

112. Pérez-Rodríguez, F.; Valero, A.; Todd, E.C.D.; Carrasco, E.; García-Gimeno, R.M.; Zurera, G. Modeling transfer of Escherichia coli O157: H7 and Staphylococcus aureus during slicing of a cooked meat product. Meat Science, 2007 76(4), pp.692-699.

113. de Pace, F.; de Paiva, J.B.; Nakazato, G.; Lancellotti, M.; Sircili, M.P.; Stehling, E.G.; da Silveira, W.D.; Sperandio, V.. Characterization of IcmF of the type VI secretion system in an avian pathogenic Escherichia coli (APEC) strain. Microbiology, 2011, 157(10), pp.29542962.

114. Bermúdez-Aguirre, D.; Corradini. M.G. Inactivation kinetics of Salmonella spp. under thermal and emerging treatments: A review. Food Research International, 2012, 45(2), pp.700712 .

115. Mani-Lopez, E.; García, H.S.; López-Malo, A. Organic acids as antimicrobials to control Salmonella in meat and poultry products. Food Research International, 2012, 45(2), pp.713-721.

116. Cox, J.M.; Pavic, A. . Advances in enteropathogen control in poultry production. Journal of Applied Microbiology, 2010, 108(3), pp.745-755.

117. Duffy, G.; Cloak, O.M.; O'Sullivan, M.G.; Guillet, A.; Sheridan, J.J.; Blair, I.S.; McDowell, D.A. The incidence and antibiotic resistance profiles of Salmonella spp. on Irish retail meat products. Food Microbiology, 1999, 16(6), pp.623-631.

118. Horiuchi, T.; Gondo, H.; Miyagawa, H.; Otsuka, J.; Inaba, S.; Nagafuji, K.; Takase, K.; Tsukamoto, H.; Koyama, T.; Mitoma, H.; Tamimoto, Y. Association of mannose-binding lectin gene polymorphisms with major bacteriall infection in patients treated with high-dose chemotherapy and autologous PBSCT. Genes and immunity, 2005 6(2), p.162. 
119. Tam, M.A.; Rydström, A.; Sundquist, M.; Wick, M.J.. Early cellular responses to Salmonella infection: dendritic cells, monocytes, and more. Immunological reviews, 2008, 225(1), pp.140-162.

120. Koinarski, V.; Lyutskanov, M.; Urumova, V.. Effect of Eimeria adenoeides challenge upon the course of an experimental Salmonella Enteritidis infection in turkey poults. Turkish Journal of Veterinary and Animal Sciences, 2007, 30(5), pp.489-495.

121. Kaldhusdal, M.; Benestad, S.L.; Løvland, A. Epidemiologic aspects of necrotic enteritis in broiler chickens-disease occurrence and production performance. Avian Pathology 2016, 45(3), pp.271-274.

122. Kadykalo, S.; Roberts, T.; Thompson, M.; Wilson, J.; Lang, M.; Espeisse, O. The value of anticoccidials for sustainable global poultry production. International Journal of Antimicrobial Agents. 2017.

123. Vandeplas, S.; Dauphin, R.D.; Beckers, Y.; Thonart, P.; Thewis, A. Salmonella in chicken: current and developing strategies to reduce contamination at farm level. Journal of food protection, 2010, 73(4), pp.774-785.

124. Heitzeneder, S.; Seidel, M.; Förster-Waldl, E.; Heitger, A. Mannan-binding lectin deficiency-Good news, bad news, doesn't matter?. Clinical immunology, 2012, 143(1), pp.2238 .

125. Fieseler, L.; Doyscher, D.; Loessner, M.J.; Schuppler, M. Acanthamoeba release compounds which promote growth of Listeria monocytogenes and other bacterial. Applied Microbiology Biotechnology2014, 98:30913097

126. Dhama, K.; Wani, M.Y.; Deb, R.; Karthik, K.; Tiwari, R.; Barathidasan, R.; Kumar, A.; Mahima-Verma, A.K; Singh, S.D. Plant based oral vaccines for human and animal pathogens a new era of prophylaxis: current and future prospective. Journal Experimental Biological Agricultural Science 2013, 1:112.

127. Feng, Y.; Wu, S.; Varma, J.K.; Klena, J.D.; Angulo, F.J.; Ran, L. Systematic review of human listeriosis in China, 1964-2010. Journal of Tropical Medicine and International Health. doi:10.1111/tmi.12173. 2013 18(10), pp. 1248-1256.

128. Yang, Y.; Xu, F.; Xu, H.; Aguilar, Z.P.; Niu, R.; Yuan, Y.; Sun, J.; You, X.; Lai, W.; Xiong, Y.; Wan, C.,. Magnetic nano-beads based separation combined with propidium monoazide treatment and multiplex PCR assay for simultaneous detection of viable Salmonella Typhimurium, Escherichia coli O157: H7 and Listeria monocytogenes in food products. Food microbiology, 2013, 34(2): pp 418-424.

129. Lamont, R.J.; Postlethwaite, R. Carriage of Listeria monocytogenes and related species in pregnant and non-pregnant women in Aberdeen, Scotland. Journal of Infection, 1986, 13(2), pp.187-193. 
130. Sheridan, J.J.; Doherty, A.; Allen, P.; McDowell, D.A.; Blair, I.S. and Harrington, D. Investigations on the growth of Listeria monocytogenes on lamb packaged under modified atmospheres. Food Microbiology, 1995, 12, pp.259-266.

131. OIE. 2014. Listeria monocytogenes. Chapter 2.9.7. Manual of diagnostic tests and vaccines for terrestrial animals. p.118. Available from: http://www.oie.int/manual-of-diagnostic-tests-andvaccines-for-terrestrial-animals/

132. Dhama, K.; Verma, V.; Sawant, P.M.; Tiwari, R.; Vaid, R.K; Chauhan, R.S. Applications of probiotics in poultry: enhancing immunity and beneficial effects on production performances and health a review. Journal Immunology Immunopathology 2011, 13:119

133. Huang, Y.T.; Liao, C.H.; Yang, C.J.; Teng, L.J.; Wang, J.T.; Hsueh, P.R. Listeriosis, Taiwan, 19962008. Emergency Infection District 2011, 17:17311733.

134. De Villiers 2017. https://www.news24.com/SouthAfrica/News/meat-at-gauteng-abattoirtests-positive-for-listeria-pathogen-20171230

135. Tiwari, R.; Dhama, K.; Wani, M.Y.; Verma, V.; Vaid, R.K.; Chauhan, R.S. Bacteriophage therapy a novel tool for combating bacteriall diseases of poultry a review. Journal Immunology Immunopathology 2011; 13:5566

136. Klumpp, J.; Loessner, M.J. Listeria phages: genomes, evolution, and application. Bacteriophage. 2013; $3: \mathrm{e} 26861$

137. Bigot, B.; Lee, W.J.; McIntyre, L.; Wilson, T.; Hudson, J.A.; Billington, C.; Heinemann J.A. Control of Listeria monocytogenes growth in a ready-to-eat poultry product using a bacteriophage. Food Microbiology 2011, 28:14481452.

138. Gopi, M.; Karthik, K.; Manjunathachar, H.V.; Tamilmahan, P.; Kesavan, M.; Dashprakash, M.; Balaraju, B.L.; Purushothaman, M.R. Essential oils as a feed additive in poultry nutrition. Advance Animal Veterinary Science 2014, 2:17.

139. Tosun, G.; Kahriman, N.; Albay, C.G.; Karaoglu, S.A.; Yayli, N. Antimicrobial activity and volatile constituents of the flower, leaf, and stem of Paeonia daurica grown in Turkey Turkey Journal Chemistry. 2011, 35:145153.

140. Lim, J.Y.; Yoon, J.W.; Hovde, C.J. A brief overview of Escherichia coli O157: H7 and its plasmid O157. Journal of microbiology and biotechnology, 2010, 20(1), p.5.

141. Hong, S.I; Rhim J.W. Antimicrobial activity of organically modified nano-clays. Journal of Nanoscience Nanotechnology 2008, 8:58185824.

142. Crhanova, M., Hradecka, H., Faldynova, M., Matulova, M., Havlickova, H., Sisak, F.; Rychlik, I. Immune response of chicken gut to natural colonization by gut microflora and to Salmonella enterica serovar enteritidis infection. Infection and immunity, 2011, 79(7), pp.27552763

143. Takele, T.; Oli, W.. Uses and flock management practices of scavenging chickens in Wolaita Zone of southern Ethiopia. Trop. Anim. Health Prod, 2011, 44, pp.537-544. 
144. Muchadeyi, F.C.; Sibanda S.; Kusina N.T.; Kusina J.; Makuza, S.. The village chicken production system in Rushinga District of Zimbabwe. Livestock Research for Rural Development, 2004, 16, Art. \#40. Retrieved October 3, 2017, from http://www.lrrd.org/lrrd16/6/much16040.htm

145. Badubi, S.S., Rakereng, M.; Marumo, M.,. Morphological characteristics and feed resources available for indigenous chickens in Botswana. Livestock Research for Rural Development, 2006, 18(1), pp.205-211.

146. Kitalyi, A.J. Village chicken production systems in rural Africa: Household food security and gender issues (No. 142). 1998, Food \& Agriculture Organization.

147. Ahmadifar, E., Mansour, M.R., Amirkolaie, A.K.; Rayeni, M.F. Growth efficiency, survival and haematological changes in great sturgeon (Huso huso Linnaeus, 1758) juveniles fed diets supplemented with different levels of thymol-carvacrol. Animal Feed Science and Technology, 2014, 198, pp.304-308.

148.Udayamputhoor, R. S., Hariharan, H. van Lunen, T.A., Lewis, P.J., Heaney, S., Price, L.; Woodward. D. Effects of diet formulations containing proteins from different sources on intestinal colonization by Campylobacter jejuni in broiler chickens. Canadian Journal Veterinary Research, 2003, 67:204-212.

149. Jack, D.L.; Klein, N.J.; Turner, M.W. Mannose-binding lectin: targeting the microbial world for complement attack and opsonophagocytosis. Immunological reviews; 2001, 180: 8699. pmid: 11414367

150. Darnton-Hill, I.; Ahmed, F.; Samman, S. The impact of micronutrients on inflammation and health in low-and middle-income countries. In Preventive Nutrition 2015, (pp. 597-644). Springer International Publishing

151. Soni, N.; Mishra, S.K.; Swain, R.; Das, A.; Chichilichi, B. and Sethy, K. Bioavailability and immunity response in broiler breeders on organically complexed zinc supplementation. Food and Nutrition Sciences, 2013, 4(12), p.1293.

152. Bullen, J. J.; Rogers, H.J.; Spalding, P.B and Ward, C.G. Iron and infection: the heart of the matter. FEMS Immunology Medical Microbiology, 2005, 43:325-330.

153. Rahman, M.T.; and Karim, M.M. Metallothionein: a Potential Link in the Regulation of Zinc in Nutritional Immunity. Biological Trace Element Research, 2017; pp.1-13. 
Table 1: Shows bacterial, organisms and site of binding mannose-binding lectin

\begin{tabular}{llll}
\hline Bacterial & Organisms & Site of binding & References \\
\hline Bifidobacteriumbifidum & Chicken & Serum & {$[48]$} \\
Burkholderiacepacia & Chicken & Carbohydrates structure & {$[48]$} \\
Chlamydia pneumonia & Chicken & Serum & {$[49]$} \\
Escherichia coli & Chicken & Carbohydrates Structure & {$[50]$} \\
Fusobacterium spp & Ruminant/ monogastric & Serum & {$[51]$} \\
Haemophilus influenza & Monogastric & Serum & {$[48]$} \\
Leptotrichi abuccalis & Chicken and Avian species & Serum & {$[52]$} \\
Listeria monocytogens & Chicken & Serum & {$[48]$} \\
Mycobacterium avium & Avian species & Serum & {$[52]$} \\
Neisseria meningitides & Livestock & MASP & {$[53]$} \\
Proprionibacterium acnes & Avian species & MASP 1 and 2 & {$[51]$} \\
Staphylococcus aureus & Avian species & MASP 1 and 2 & {$[48]$} \\
Streptococcus pneumoniae & Avian species & MASP 1 and 2 & {$[52]$} \\
Campylobacter spp & Avian species & MASP 1 and 2 & {$[51]$} \\
\hline
\end{tabular}


Table 2: past methods of detecting mannose binding lectin

\begin{tabular}{|c|c|c|c|c|}
\hline Organism & $\begin{array}{l}\text { Mannose-binding lectin } \\
\text { Assay, detection and } \\
\text { sample volume }\end{array}$ & $\begin{array}{l}\text { Cross Reactivity and } \\
\text { Interference }\end{array}$ & Price and Sample Size & References \\
\hline Chicken & Baker's Yeast & Less sensitive & $\begin{array}{l}\text { Small sample } 1-10 \text { sample sizes, } \\
\text { consumes time, less reliable and less } \\
\text { reproducible }\end{array}$ & [54] \\
\hline $\begin{array}{l}\text { Human Adult } \\
\text { Homosapiens }\end{array}$ & Baker's yeast & Not Sensitive & Small sample size and not expensive & {$[61]$} \\
\hline Pediatric Patient & $\begin{array}{l}\text { Nephelometric Assay } \\
0.09-5.6 \mathrm{ug} / \mathrm{ml} \\
\text { Sample volume of } 44 \mathrm{ul}\end{array}$ & $\begin{array}{l}\text { Not specific capture and } \\
\text { primary detection. Used } \\
\text { Rabbit anti- antibody } \\
\text { Shorter Assay Time but not } \\
\text { reliable and Less- Sensitive }\end{array}$ & Expensive and Large Sample size & [76] \\
\hline $\begin{array}{l}\text { Children } \\
0.1-15.9 \text { years }\end{array}$ & $\begin{array}{l}\text { Nephelometric Assay } \\
0.09-5.6 \mathrm{ug} / \mathrm{ml}\end{array}$ & Less Sensitive & $\begin{array}{l}\text { Large Sample Size and Less } \\
\text { Expensive }\end{array}$ & [77] \\
\hline
\end{tabular}


Table 3: Present and Future methods of detecting mannose-binding lectin

\begin{tabular}{|c|c|c|c|c|}
\hline Organism & $\begin{array}{l}\text { Mannose-binding lectin } \\
\text { Assay, detection } \\
\text { and sample volume }\end{array}$ & $\begin{array}{l}\text { Cross Reactivity } \\
\text { and Interference }\end{array}$ & Price and Sample Size & References \\
\hline Human Adult & $\begin{array}{l}\text { ELISA } \\
0.05-2.5 \mathrm{Ag} / \mathrm{ml}\end{array}$ & $\begin{array}{l}\text { Specific capture and primary } \\
\text { detection antibodies. Short } \\
\text { Assay Time and very sensitive }\end{array}$ & $\begin{array}{l}\text { Very Expensive } \\
\text { and Medium Sample Size }\end{array}$ & [78] \\
\hline Pediriatric patients & ELISA & $\begin{array}{l}\text { Not Specific monoclonal and } \\
\text { polyclonal detection } \\
\text { Short Assay time, sensitive and } \\
\text { reliable }\end{array}$ & Expensive & [76] \\
\hline $\begin{array}{l}\text { Chicken } \\
\text { Gallus gallus domestica }\end{array}$ & $\begin{array}{l}\text { ELISA } \\
\text { Combine } \\
\text { use of ELISA and PCR }\end{array}$ & $\begin{array}{l}\text { Specific monoclonal and } \\
\text { polyclonal detection } \\
\text { Very reliable }\end{array}$ & $\begin{array}{l}\text { Expensive and } \\
\text { Medium sample size }\end{array}$ & {$[79,23,80]$} \\
\hline $\begin{array}{l}\text { Mice } \\
\text { Mus }\end{array}$ & ELISA & Very Reliable & $\begin{array}{l}\text { Expensive and } \\
\text { medium sample size }\end{array}$ & [29] \\
\hline $\begin{array}{l}\text { Chicken } \\
\text { Gallus gallus domestica }\end{array}$ & $\begin{array}{l}\text { Genomic DNA } \\
\text { Real Time PCR } \\
\text { Multiplex PCR }\end{array}$ & $\begin{array}{l}\text { Two-step real-time reverse } \\
\text { transcription PCR (real-time } \\
\text { RT-PCR) method. }\end{array}$ & $\begin{array}{l}\text { Extremely Expensive, } \\
\text { highly reproducible and } \\
\text { highly reliable }\end{array}$ & {$[83,84]$} \\
\hline Human & $\begin{array}{l}\text { DNA Typing } \\
\text { Real Time PCR } \\
\text { Multiplex PCR }\end{array}$ & $\begin{array}{l}\text { Detection of } \\
\text { allele, Haplotyping, } \\
\text { sequence-specific } \\
\text { oligonucleotide probes, } \\
\text { amplification of the variants }\end{array}$ & $\begin{array}{l}\text { Economical and renders rapid } \\
\text { reliable results without } \\
\text { ambiguities. } \\
\text { Hardy-Weinberg correlated, }\end{array}$ & [85] \\
\hline
\end{tabular}




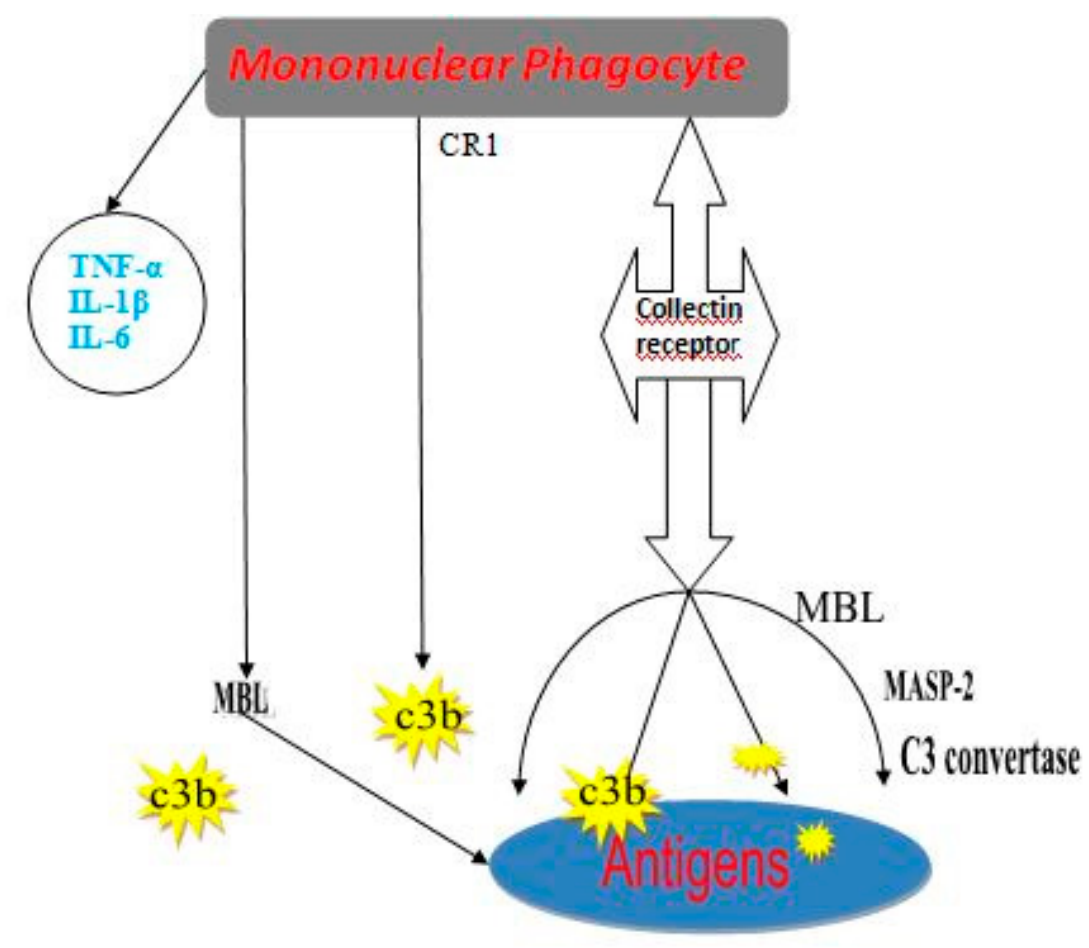

Fig 1: Diagrammatic structure of mannose-binding lectin attaching itself to bacterial pathogens [41]. 